\title{
Review
}

\section{Understanding the importance of selenium and selenoproteins in muscle function}

\author{
M. Rederstorff, A. Krol and A. Lescure* \\ UPR 9002 du CNRS ARN 'Architecture et Réactivité de l'arN', Institut de Biologie Moléculaire et Cellulaire, 15 \\ rue René Descartes, 67084 Strasbourg Cedex (France), Fax: +33388602218, e-mail: a.lescure@ ibmc.u-strasbg.fr
}

Received 13 July 2005; received after revision 9 September 2005; accepted 4 October 2005

Online First 28 November 2005

\begin{abstract}
Selenium is an essential trace element. In cattle, selenium deficiency causes dysfunction of various organs, including skeletal and cardiac muscles. In humans as well, lack of selenium is associated with many disorders, but despite accumulation of clinical reports, muscle diseases are not generally considered on the list. The goal of this review is to establish the connection between clinical observations and the most recent advances obtained in selenium biology. Recent results about a
\end{abstract}

possible role of selenium-containing proteins in muscle formation and repair have been collected. Selenoprotein $\mathrm{N}$ is the first selenoprotein linked to genetic disorders consisting of different forms of congenital muscular dystrophies. Understanding the muscle disorders associated with selenium deficiency or selenoprotein $\mathrm{N}$ dysfunction is an essential step in defining the causes of the disease and obtaining a better comprehension of the mechanisms involved in muscle formation and maintenance.

Key words. Selenium; selenoprotein; muscle disorders; congenital muscular dystrophy; SEPN1.

\section{Introduction}

Discovered in 1817 by Berzelius, selenium was considered originally and for a long time as a vicious poison. It is only in the mid-1950s that the physiological significance of this trace element was correctly evaluated. Identification of pathologies related to selenium deficiencies demonstrated its essential nutrient function, first in livestock and next in humans [1]. Since then, compiling evidence has shown the importance of selenium in prevention of cancer, cardiovascular diseases and viral infections, as well as thyroid and immune system functions, fertility and aging (reviewed in [2-4]). The multiplicity of the diseases, and the absence of evident link between them, suggested that selenium is involved in multiple biologi-

\footnotetext{
* Corresponding author.
}

cal processes. Biochemistry and molecular biology have contributed to deciphering these activities by determining the molecular mechanisms in which this compound is involved.

Primarily, biochemical studies identified selenocysteine as the major biological form of selenium in animals and bacteria. This particular amino acid is specifically incorporated into selenoproteins through a dedicated translation machinery [5]. Using genomics and bioinformatics data mining, the almost complete repertoire of selenoproteins was identified in both animals and bacteria ([6, 7] and for a review see [8]). Twenty-six different selenoproteins were identified in higher eukaryotes, though the function of many of them remains unknown (table 1). Selenoproteins of known function are all oxidoreductase intervening enzymes, implicated in multiple metabolic pathways, e.g., free radical scavenging, maintenance of intracellular redox status, repair of oxidized lipids or 
Table 1. Selenoproteins identified in eukaryotes.

\begin{tabular}{|c|c|c|c|c|}
\hline $\begin{array}{l}\text { Seleno- } \\
\text { protein }\end{array}$ & $\begin{array}{l}\text { Chromosomal } \\
\text { location in } \\
\text { humans }\end{array}$ & Catalytic function & & Schematic representation \\
\hline $15 \mathrm{kDa}$ & $1 \mathrm{p} 22.3$ & $\begin{array}{l}\text { involved in the protein } \\
\text { reticulum }\end{array}$ & control within the endoplasmic & $\square$ \\
\hline DI1 & $1 \mathrm{p} 32.3$ & thyroid hormone matu & & $\square$ \\
\hline DI2 & $14 \mathrm{q} 31.1$ & thyroid hormone matu & & $\square$ \\
\hline DI3 & $14 \mathrm{q} 32$ & thyroid hormone catab & & $\square$ \\
\hline GPx1 & $3 \mathrm{p} 21.31$ & cytoplasmic, free-radic & ction & $\square$ \\
\hline GPx2 & $14 \mathrm{q} 23.3$ & plasmatic, free-radical & & 口 \\
\hline GPx3 & $5 \mathrm{q} 33.1$ & gastrointestinal, free-ra & eduction & C्ع \\
\hline GPx4 & $19 \mathrm{p} 13.3$ & $\begin{array}{l}\text { oxidized phospholipid } \\
\text { during spermatogenesi }\end{array}$ & on and chromatin condensation & $\square$ \\
\hline GPx6 & $6 \mathrm{p} 22.1$ & $\begin{array}{l}\text { free-radical reduction, } \\
\text { highly expressed in olf }\end{array}$ & $\begin{array}{l}\text { cysteine in pig and man only, } \\
\text { epithelium }\end{array}$ & $\sqsubset$ \\
\hline $\mathrm{H}$ & $11 \mathrm{q} 12.1$ & unknown & & $\square$ \\
\hline I & $2 \mathrm{p} 23.3$ & unknown & & (1) \\
\hline $\mathrm{J}$ & - & $\begin{array}{l}\text { unknown, present in fis } \\
\text { in jellyfishes }\end{array}$ & d sea urchin, cysteine homologues & r \\
\hline $\mathrm{K}$ & $3 \mathrm{p} 21.31$ & unknown & & $\square$ \\
\hline M & $22 q 12.2$ & unknown & & $\square$ \\
\hline $\mathrm{N}$ & $1 \mathrm{p} 35.36$ & $\begin{array}{l}\text { unknown, associated to } \\
\text { endoplasmic reticulum }\end{array}$ & $\begin{array}{l}\text { dlar diseases, localized in the } \\
\text { rane }\end{array}$ & \\
\hline $\mathrm{O}$ & $22 q 13.33$ & unknown & & 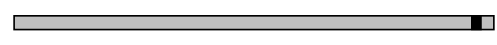 \\
\hline $\mathrm{P}$ & $5 \mathrm{p} 12$ & nitrite reductase and $\mathrm{pl}$ & c selenium transport & 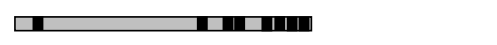 \\
\hline S & $15 \mathrm{q} 26.3$ & unknown, localized in & loplasmic reticulum membrane & $\square$ \\
\hline SPS2 & $16 \mathrm{p} 11.2$ & selenophosphate synth & elenocysteine metabolism & $\square$ \\
\hline $\mathrm{T}$ & $3 q 24$ & unknown & & \\
\hline TR1 & $12 \mathrm{q} 23.3$ & $\begin{array}{l}\text { cytoplasmic } \\
\text { thioredoxin reductase }\end{array}$ & redox enzymes involved in & $\sqsubset$ \\
\hline TR2 & $3 q 21.2$ & $\begin{array}{l}\text { mitochondrial } \\
\text { thioredoxin reductase }\end{array}$ & $\begin{array}{l}\text { muitipie biosynthetic pathways } \\
\text { and regulation mechanisms }\end{array}$ & \\
\hline TR3 & $22 \mathrm{q} 11.21$ & $\begin{array}{l}\text { thioredoxin/glutathion } \\
\text { important for sperm m }\end{array}$ & $\begin{array}{l}\text { tase, disulfide isomerase, } \\
\mathrm{n}\end{array}$ & 10 \\
\hline $\mathrm{U}$ & - & $\begin{array}{l}\text { unknown, selenocystei } \\
\text { and diatoms only }\end{array}$ & sh, birds, sea urchins, green algae & $\square$ \\
\hline $\mathrm{V}$ & $19 q 13.13$ & unknown, highly expre & testis & במس \\
\hline $\mathrm{W}$ & $19 q 13.32$ & unknown, associated u & diac calcification & 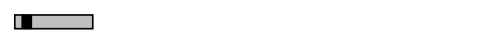 \\
\hline MsrA & - & $\begin{array}{l}\text { methionine-S-sulfoxid } \\
\text { reinhardtii only }\end{array}$ & tase, selenocysteine in $C$. & \\
\hline $\begin{array}{l}\text { MsrB } \\
(\mathrm{X} / \mathrm{R})\end{array}$ & $16 \mathrm{p} 13.3$ & methionine-R-sulfoxid & tase & (1) \\
\hline
\end{tabular}

Human chromosomal locations and characterized functions are indicated. The relative position of the selenocysteine residue is indicated by a dark box. DI: iodothironine deiodinase; GPx: glutathione peroxidase.

methionines. Other selenoproteins are involved in thyroid hormone metabolism, selenocysteine synthesis or in different steps of sperm maturation. In all documented cases, selenocysteine was shown to take part directly in the catalytic reaction. Selenocysteine functions as an extraordinarily reactive cysteine homologue. This increased reactivity is usually regarded as the 'raison d'être' for selenoproteins, despite their costly and inefficient synthesis machinery ([9] and references included).
Up to now, only a few molecular mechanisms have been demonstrated that establish direct links between selenoprotein dysfunctions and the diseases caused by selenium deprivation. Among unexplained deficiencies are different forms of muscular diseases whose conditions remain elusive (reviewed in [10]). Older observations together with recent findings demonstrated a clear role for selenium and certain selenoproteins in muscle physiology and their implication in muscular diseases (table 2). 
Table 2. Overview of Human and animal muscular disorders provoked by selenium or selenoprotein deprivation.

\begin{tabular}{|c|c|c|c|c|}
\hline & Disease & Conditions & Symptoms & References \\
\hline \multirow[t]{8}{*}{ In humans } & Keshan disease & $\begin{array}{l}\text { low selenium diet and } \\
\text { Coxsackie virus infection }\end{array}$ & $\begin{array}{l}\text { cardiomyopathy: necrotic lesions, inflammatory } \\
\text { areas, calcification through myocardium }\end{array}$ & 17,18 \\
\hline & $\begin{array}{l}\text { Nutritional myotonic } \\
\text { dystrophy }\end{array}$ & low selenium diet & muscle pain and weakness & $24-26$ \\
\hline & $\begin{array}{l}\text { Nutritional myotonic } \\
\text { dystrophy }\end{array}$ & $\begin{array}{l}\text { parenteral or enteral } \\
\text { nutrition }\end{array}$ & muscle pain and weakness & $21-23$ \\
\hline & $\begin{array}{l}\text { Chronic muscle } \\
\text { disorder associated } \\
\text { with oxidative stress }\end{array}$ & $\begin{array}{l}\text { alcohol } \\
\text { HIV infection }\end{array}$ & muscle pain and weakness & 29,30 \\
\hline & $\begin{array}{l}\text { Rigid spine muscular } \\
\text { dystrophy }\end{array}$ & & & $31,32,46$ \\
\hline & Multiminicore disease & & & 48 \\
\hline & $\begin{array}{l}\text { Mallory body-like } \\
\text { desmin-related } \\
\text { myopathy }\end{array}$ & $\begin{array}{l}\text { mutations in the } \\
\text { selenoprotein } \mathrm{N} \text { gene }\end{array}$ & $\begin{array}{l}\text { hypotonia, predominance of axial muscle } \\
\text { weakness, scoliosis, sarcomeric disorganization,... }\end{array}$ & 55 \\
\hline & $\begin{array}{l}\text { Dropped head } \\
\text { syndrome }\end{array}$ & & & 58 \\
\hline \multirow[t]{4}{*}{ In animals } & $\begin{array}{l}\text { Nutritional muscular } \\
\text { dystrophy (chicken, } \\
\text { turkey, salmon,...) }\end{array}$ & low selenium diet & cardiac and skeletal muscle affections & $11-14$ \\
\hline & White muscle & $\begin{array}{l}\text { low selenium diet inducing } \\
\text { disease (calf)low concen- } \\
\text { tration in selenoprotein W }\end{array}$ & $\begin{array}{l}\text { alterations of cardiac and skeletal muscles, } \\
\text { extensive calcification }\end{array}$ & 15,41 \\
\hline & $\begin{array}{l}\text { Rigid lamb } \\
\text { syndrome }\end{array}$ & $\begin{array}{l}\text { combined selenium and } \\
\text { vitamin E deficiency }\end{array}$ & rigidity of the limbs and spine & 16 \\
\hline & $\begin{array}{l}\text { Fatal myopathy } \\
\text { (guinea pig) }\end{array}$ & $\begin{array}{l}\text { combined selenium and } \\
\text { vitamin E deficiency }\end{array}$ & $\begin{array}{l}\text { muscle affection, lipid peroxidation, } \\
\text { low glutathione peroxidase }\end{array}$ & 36 \\
\hline
\end{tabular}

\section{The importance of selenium in muscle physiology}

Shortly after selenium acquired the status of essential trace element, dispersed publications reported its important role in muscle function. A lack of selenium associated with several muscular diseases affecting both cardiac and skeletal muscles was described in both cattle and humans, defining a new syndrome called nutritional muscular dystrophy [11-14]. White muscle disease (WMD) in cows, calves and sheep, or rigid/stiff lamb syndrome (RL) are myopathies characterized by the alteration of cardiac and skeletal muscle fibers with extensive calcification as an often-observed feature. Emergence of these diseases is strongly influenced by diet, and a direct link between the selenium content of the food and the incidence of the diseases could be established $[15,16]$. Finally, a good protection against WMD or RL emergence by selenium supplementation demonstrated the importance of this trace element.

In humans, Keshan disease is another selenium-related disorder occurring in different regions of eastern China where the selenium content of the soil is very low (for review, [17]). This disease corresponds to a cardiomyopathy, characterized by necrotic lesions, inflammatory areas and calcification throughout the myocardium [18]. Experimental approaches in mouse suggested a dual etiology for the disease. It is caused by both a dietary deficiency in the trace element and an infection by a nonvirulent strain of the enterovirus Coxsackie. The virus became virulent after passage in a selenium-deficient host [19]. Mutations occurred in the genome of the harmless viral strain, turning it into a cardiovirulent one. The pathogenicity and irreversibility of the mutation were demonstrated as the modified viral strain also provoked heart damage in adequate selenium mice. Moreover, identical results were obtained from a glutathione peroxidase knockout mouse strain, indicating the essentiality of this selenoenzyme to prevent the oxidative mutations of the viral genome [20].

Prolonged parenteral nutrition is another cause for severe selenium deficiency associated with skeletal muscle disorders [21-23]. A lower glutathione peroxidase activity, indicative of the low cellular selenium status, was associated with muscle pain and weakness. In these cases, the affected patients responded favorably to selenium administration [24]. The effects of selenium administration were also tested in patients featuring myotonic dystrophies, since it was observed that their selenium 
level in blood decreased with the evolution of the disease [25]. Even if no positive effects of selenium administration could be generally observed, one myotonic dystrophy patient presented an improvement of his muscular strength in parallel with the diminution of the pathological symptoms [26]. Conversely, supplementation studies in the case of Duchenne or Becker human muscular dystrophies did not show improvement, suggesting they may not be selenium-linked [27, 28]. Different responses to selenium administration in muscular dystrophic patients suggested different etiologies. In isolated cases, mitochondrial alterations were described in muscle biopsies from patients presenting muscle disorders associated with selenium deficiency, and a possible connection to oxidative damage was suggested $([29,30]$ and for a review see [10]).

More direct evidence establishing the connection between muscle dysfunction and selenium was obtained as the group of Guicheney demonstrated that a form of congenital muscular dystrophy is caused by mutations in a gene encoding a newly characterized selenium-containing protein, the selenoprotein $\mathrm{N}$ [31-33].

\section{A conflicting connection to vitamin $\mathbf{E}$}

Vitamin E/tocopherol deficiency is often linked to selenium deficiency. Actually, the simultaneous lack of selenium and vitamin $\mathrm{E}$ is the cause of most known syndromes. The first studies, aimed at reproducing these diseases under controlled feeding conditions, failed to establish any relation between the tocopherol content and WMD occurrence, contrary to what was observed for selenium. Nonetheless, incidence of rigid lamb syndrome was lowered by simultaneous administration of selenium and vitamin $\mathrm{E}$ to ewes [15]. Other studies indicated a more important role for vitamin E. For instance, when using a diet low in selenium only, a less marked incidence of the disease was observed [34]. A French group could even separate the two deficiencies to obtain distinct, although clinically related myopathies [35]. Finally, a study demonstrated that combined selenium and vitamin E deficiencies resulted in systemic fatal myopathy in the guinea pig, whereas the pathology was much less severe in the case of single deficiency [36]. In the affected muscles, lipid peroxidation was observed and associated with a decrease in glutathione peroxidase activity, probably reflecting the lack of selenium. It was also shown that no myopathy occurred in calves when the diet was low in selenium, adequate in tocopherol and low in polyunsaturated fatty acids [37].

Therefore, vitamin E appears as a factor exacerbating the lack in selenium, but the mechanism is not understood. Indeed, the complete panel of functions of vitamin $\mathrm{E}$ is not known yet. Its antioxidative properties suggest that it is involved in prevention of oxidative stress, but vitamin E functions are clearly undervalued, and this molecule might be involved in more specific reactions remaining to be characterized (for a review, see [38]).

\section{Selenoproteins in muscle tissue}

Since selenium is incorporated into proteins in the form of selenocysteine, muscular selenoproteins were investigated in animals affected with WMD. After administration of ${ }^{75} \mathrm{Se}$ to lambs, radioactive muscle proteins were analyzed, allowing identification of the selenoprotein $\mathrm{W}[39,40]$. Selenoprotein $\mathrm{W}$ is a protein present at high level in muscles from selenium-supplemented animals, but almost undetectable in those presenting WMD (table 1) [41]. The sarcoplasmic reticulum in the muscle of WMD animals has lost its ability to sequester calcium, resulting in the calcification of both skeletal and cardiac muscle tissues [42]. The direct implication of selenoprotein $\mathrm{W}$ in this process remains to be established since the overall level of most selenoproteins in the muscle might be lowered in the case of selenium deficiency, and the precise function of selenoprotein $\mathrm{W}$ has yet to be elucidated. It was reported that selenoprotein W both binds glutathione [43] and shows glutathione-dependent antioxidant activity in vivo [44].

\section{Selenoprotein $\mathbf{N}$, the missing link}

Identification of novel selenoproteins through bioinformatic approaches provided new paths to the identification of physiological disorders associated with selenium deficiency. Among the new proteins is selenoprotein N, a protein of unknown function [33, 45]. Its gene, SEPN1, was localized on chromosome 1 at position p35-36 (table 1). This position corresponds to the locus associated with rigid spine muscular dystrophy (RSMD) [31]. This is a rare congenital muscular disease characterized by early onset of hypotonia, predominance of axial muscle weakness leading to life-threatening respiratory insufficiency and scoliosis (table 2) [46]. This locus was further restricted to a region containing about 20 genes, including the selenoprotein $\mathrm{N}$ gene. According to the multiple observations supporting the role of selenium in muscle physiology, the SEPN1 gene appeared to be a good candidate for RSMD. Indeed, sequencing of the SEPN1 gene from affected patients identified several mutations in different families [32], establishing for the first time a connection between a selenoprotein and a human genetic disorder. However, the precise role of selenoprotein $\mathrm{N}$ in the muscle must be further investigated, since its biochemical function remains unknown.

Based on convergent clinical and morphological information, a connection between the classical form of mul- 
timinicore disease $(\mathrm{MmD})$ and selenoprotein $\mathrm{N}$ was also assumed. $\mathrm{MmD}$ is a heterogeneous congenital myopathy from which four subgroups can be distinguished. The moderate form of $\mathrm{MmD}$ is provoked by mutations in the ryanodine receptor type 1 gene [47]. For the other three forms, among which the most current and severe is called classical MmD, the causative genes were unknown. The analysis of 27 informative families with $\mathrm{MmD}$ showed a linkage to the RSMD1 locus for 8 of them, featuring the classical form of the disease [48]. Sequencing the SEPN1 gene in the 8 families linked to the RSMD1 locus and in 14 additional sporadic patients featuring the classical phenotype identified 9 possible mutations. Three of them were previously described in RSMD patients, and 6 were totally new ones. These studies contributed to the definition of a selenoprotein $\mathrm{N}$-related myopathy class.

In another heterogeneous group of muscle disorders, the desmin-related myopathies or desminopathies (DRMs), no responsible gene was assigned for two-thirds of the cases $[49,50]$. These diseases are characterized by accumulation of desmin and different other protein aggregates into the cytoplasm of muscle fibers [51, 52]. In $30 \%$ of the cases, a mutation in the desmin gene was proven to be responsible for the disease $[49,50]$. In another family, a mutation in the $\alpha-\beta$ crystallin gene was identified for the same disease [53, 54]. The latter disease is now also called $\alpha-\beta$ crystallinopathy. In an alternative form of the disease, MB-DRM, featuring Mallory bodylike inclusions, the causative gene was not determined. The presence of similar inclusion bodies in two cases of selenoprotein $\mathrm{N}$-related myopathies suggested a link between MB-DRM and selenoprotein N. Analysis of four MB-DRM patients of the same German family demonstrated a relationship between the disease and the selenoprotein $\mathrm{N}$ locus, pointing at a new selenoprotein $\mathrm{N}$ gene deletion [55]. This interesting finding illustrates the heterogeneity of DRM, and increases the broad spectrum of the selenoprotein N-related myopathies. Since these initial characterizations, more reports on novel mutations in selenoprotein $\mathrm{N}$ gene have been collected from different patients presenting early onset myopathy [56-58].

One striking conclusion of these findings resides in the fact that mutations in the SEPN1 gene are the condition for three different but related forms of congenital muscular dystrophy. The congenital muscular dystrophies are a clinically and genetically heterogeneous group of inherited neuromuscular disorders. Each form presents a characteristic, sometimes overlapping-phenotype, and their classification is based on a combination of clinical descriptions and characterized protein defects (for a review, see [59]). Concerning SEPN1, the different mutations do not appear to be specific to each pathological form as several mutations are shared by RSMD, MmD or MB-DRM disorders. This observation suggests that the three entities actually consist of different expressions of the same disease and that Selenoprotein N dysfunction has a large myopathological spectrum depending on other genetic or environmental factors. The hallmark of these diseases is a predominant affection of the axial muscle, leading to severe scoliosis and respiratory insufficiency [55]. The principal property of these muscles consists in their constant tonic contraction in order to sustain the permanent posture, possibly involving specific mechanical or physiological constraints connected to selenoprotein $\mathrm{N}$ cellular function. At the microscopic level, a defect of this protein appears to cause focal sarcomere disorganization, mitochondria depletion (mini-cores) and abnormal accumulation of multiple filamentous proteins, including desmin, within cytoplasmic foci. Further insight into selenoprotein $\mathrm{N}$ function is therefore the next milestone to reach for better understanding the conditions allowing the development of the diseases.

For the moment, biochemical data have demonstrated that selenoprotein $\mathrm{N}$ is a $65-\mathrm{kDa}$ transmembrane glycoprotein localized within the endoplasmic reticulum [60]. This subcellular compartment plays different important roles relevant to muscular function: calcium sequestration and controlled release during contraction; connection to the cytoskeleton; synthesis, folding and glycosylation of membrane or membrane-associated proteins involved in cell-to-cell adhesion (for a review, [61]). Which of these pathways selenoprotein $\mathrm{N}$ is involved in, is presently unknown. Several genes, the products of which are involved in post-translational modification of proteins, were shown to be the targets of mutations causing other forms of congenital muscular dystrophies, such as Walker-Warburg syndrome, muscle-eye-brain disease and Fukuyama muscular dystrophy. The corresponding enzymes, POMT1/POMT2, POMGnT1, Fukutin, FKRP and the protein LARGE, have activity related to protein O-mannosylation and glycosylation pathways. They are located either within the endoplasmic reticulum or the cis-Golgi apparatus (for reviews, see [59, 62]). Deficiency in post-translational modification of $\alpha$-dystroglycan is a common feature of these muscular diseases. This abnormally modified $\alpha$-dystroglycan is deficient in binding to extracellular matrix ligands, including laminin/ merosin and agrin, and is therefore believed to disrupt the trans-sarcolemmal linkage between the actin membrane cytoskeleton and the extracellular matrix. Thus, impaired $\alpha$-dystroglycan affects the mechanical and probably also the signaling linking properties between cells, and therefore is likely to cause rupturing of the destabilized surface membrane in muscle fibers [63, 64]. A possible role for selenoprotein $\mathrm{N}$ in another related protein modification mechanism remains to be uncovered.

Genomic studies identified a protein homologous to selenoprotein $\mathrm{N}$ in all vertebrates and even in their close ancestor, the ascidian Ciona intestinalis. However, no related candidate could be detected in insects or lower 
eukaryotes, making this gene a singularity of the chordate phylum. Moreover, the protein sequence is highly conserved through evolution. Analysis of the expression pattern of the selenoprotein $\mathrm{N}$ gene revealed that it is ubiquitously expressed in all tissues examined, an observation difficult to reconcile with the muscle-specific phenotype associated with mutations in the gene. However, the expression level was much higher in fetal tissues than in adult ones. Studies using cell cultures showed that a selenoprotein $\mathrm{N}$ higher expression is found in proliferating fibroblasts and is progressively decreased during the differentiation steps to myoblasts and then myotube formation [60]. In addition, the study of selenoprotein $\mathrm{N}$ expression in zebrafish embryo during early stages of development showed an important expression in the notochord, a precursor of the spine, and in the somites from which the skeletal muscles differentiate [65]. Collectively, these observations suggest an early developmental expression pattern, in agreement with the early onset of the disease. Obtaining animal models disabled for the selenoprotein $\mathrm{N}$ function should help to explore $\mathrm{a}$ possible role in muscle formation during development or muscle maintenance.

\section{Physiological models}

No transgenic animal knocked out for the selenoprotein $\mathrm{N}$ gene is currently available. On the other hand, analysis of the $d y / d y$ mouse [66], a laminin- $\alpha 2 /$ merosin-deficient animal model of congenital muscular dystrophy, highlighted an interesting aspect [67]. Selenocysteine insertion into proteins is mediated by a specific selenocysteine transfer RNA (tRNA ${ }^{\mathrm{sec}}$ ) (for review, [5]). In muscle tissues from these dystrophic animals, the ratio of selenocysteine tRNA ${ }^{\text {sec }}$ to serine tRNA ${ }^{\text {ser }}$ significantly increased compared with normal mice. This modification was concomitant with a higher content in the selenoenzyme glutathione peroxidase [67]. Whether this higher amount of glutathione peroxidase in affected muscles is used to prevent the enhanced oxidative stress caused by the dystrophic condition is still unclear.

Removal of the selenocysteine tRNA ${ }^{\text {sec }}$ gene in knockout mice is embryogenic lethal at an early stage [68], stressing the importance of selenoprotein synthesis to early mammalian development. To further investigate the role of selenium at the physiological level, an alternative selenoprotein-deficient mouse model was obtained by insertion into the mouse genome of 20 copies of a mutant selenocysteine tRNA ${ }^{\text {sec }}$ gene whose transcription product lacks 6-isopentenyladenosine, a modified base essential for its optimal activity [69]. Overexpression of this dominant negative-acting mutant tRNA ${ }^{\text {sec }}$ interfered with normal selenoprotein synthesis in a protein- and tissue-specific manner [70, 71]. As expected, these mice presented reduced levels of several selenoproteins in different tissues. The mice were phenotypically normal with respect to skeletal muscles, but the muscles became heavier after extensive exercise, compared with normal mice, as a result of the amplification of the adaptative response to effort [72].

The latter observation is relevant to the provocative hypothesis made by Moosmann and Behl [73], based on the observation that the use of statins in prevention and treatment of hypercholesterolaemia and coronary heart disease causes side effects such as painful responsiveness to muscle exercises and myopathy-like syndromes. These symptoms are similar to those of the muscle pathology associated with selenium deficiency. The authors suggested that molecules of the statin family might interfere with the enzymatic isopentenylation of tRNA ${ }^{\mathrm{sec}}$ and thus inhibit its maturation to a functional tRNA, resulting in a defect in selenoprotein synthesis and subsequent muscle disorders.

\section{Perspectives}

Accumulation of clinical data over several decades has provided much evidence for the essential role of selenium in human health, including muscle diseases. However, its precise role and the functional relevance of its biologically active form, the selenoproteins, in muscle formation, function and maintenance remains unclear. Interpretation of clinical results is often complicated by the fact that several observations and conclusions are contradictory owing to partial information or the limited number of patients analyzed. Biochemical studies have shed some light on this field; the discovery of selenoprotein $\mathrm{N}$ and W functions, and other selenoproteins of unknown functions, both at the molecular and physiological levels, will provide a new basis for defining the conditions leading to the onset of muscular disorders. The enhanced oxidative environment caused by the dystrophic status in muscle tissues is currently poorly understood, but the dual intervention of selenium and vitamin E suggests a possible mechanism to be elucidated. Among the numerous unanswered questions, one of the most intriguing concerns the ubiquitous expression of the SEPN1 gene, an observation rather unexpected considering the muscle-specific disorder associated with mutations in this gene. One can hypothesize that this protein is involved in a general metabolic pathway, such as protein post-translational modification, but that this reaction is rate limiting or shows a more dramatic incidence in this tissue because of muscle-specific substrate(s).

Acknowledgements. The authors gratefully acknowledge C. Allmang, M. Deniziak and P. Eftekari for their critical reading of the manuscript. 
1 Hatfield D. L. (2001) Introduction to selenium. In: Selenium: Its Molecular Biology and Role in Human Health, pp. 1-4, Hatfield D. L. (ed.), Kluwer, Boston

2 Flohe L., Andreesen J. R., Brigelius-Flohe R., Maiorino M. and Ursini F. (2000) Selenium, the element of the moon, in life on earth. IUBMB Life 49: 411-420

3 Rayman M. P. (2000) The importance of selenium to human health. Lancet 356: 233-241

4 Gladyshev V. N. (2001) Selenium in biology and human health: controversies and perspectives. In: Selenium: Its Molecular Biology and Role in Human Health, pp. 313-317, Hatfield D. L. (ed.), Kluwer, Boston

5 Lescure A., Fagegaltier D., Carbon P. and Krol A. (2002) Protein factors mediating selenoprotein synthesis. Curr. Protein Pept. Sci. 3: 143-151

6 Kryukov G. V. and Gladyshev V. N. (2004) The prokaryotic selenoproteome. EMBO Rep. 5: 538-543

7 Zhang Y. and Gladyshev V. N. (2005) An algorithm for identification of bacterial selenocysteine insertion sequence elements and selenoprotein genes. Bioinformatics 21: 25802589

8 Driscoll D. M. and Chavatte L. (2004) Finding needles in a haystack. In silico identification of eukaryotic selenoprotein genes. EMBO Rep. 5: 140-141

9 Johansson L., Gafvelin G. and Arner E. S. (2005) Selenocysteine in proteins-properties and biotechnological use. Biochim. Biophys. Acta 1726: $1-3$

10 Chariot P. and Bignani O. (2003) Skeletal muscle disorders associated with selenium deficiency in humans. Muscle Nerve 27: 662-668

11 Patterson E. L., Milstrey R. and Stokstad E. L. (1957) Effect of selenium in preventing exudative diathesis in chicks. Proc. Soc. Exp. Biol. Med. 95: 617-620

12 Schwarz K., Bieri J. G., Briggs G. M. and Scott M. L. (1957) Prevention of exudative diathesis in chicks by factor 3 and selenium. Proc. Soc. Exp. Biol. Med. 95: 621-625

13 Cantor A. H., Moorhead P. D. and Musser M. A. (1982) Comparative effects of sodium selenite and selenomethionine upon nutritional muscular dystrophy, selenium-dependent glutathione peroxidase and tissue selenium concentrations of turkey poults. Poult. Sci. 61: 478-484

14 Poston H. A., Combs G. F. Jr. and Leibovitz L. (1976) Vitamin $\mathrm{E}$ and selenium interrelations in the diet of Atlantic salmon (Salmo salar): gross, histological and biochemical deficiency signs. J. Nutr. 106: 892-904

15 Schubert J. R., Muth O. H., Oldfield J. E. and Remmert L. F. (1961) Experimental results with selenium in white muscle disease of lambs and calves. Fed. Proc. 20: 689-694

16 Rudert C. P., Lawrence J. A., Foggin C. and Barlow R. M. (1978) A rigid lamb syndrome in sheep in Rhodesia. Vet. Rec. 102: $374-377$

17 Beck M. A., Levander O. A. and Handy J. (2003) Selenium deficiency and viral infection. J. Nutr. 133: $1463 \mathrm{~S}-1467 \mathrm{~S}$

18 Gu B. Q. (1983) Pathology of Keshan disease. A comprehensive review. Chin. Med. J. (Engl.) 96: 251-261

19 Beck M. A., Shi Q., Morris V. C. and Levander O. A. (1995) Rapid genomic evolution of a non-virulent coxsackievirus B3 in selenium-deficient mice results in selection of identical virulent isolates. Nat. Med. 1: 433-436

20 Beck M. A., Esworthy R. S., Ho Y. S. and Chu F. F. (1998) Glutathione peroxidase protects mice from viral-induced myocarditis. FASEB J. 12: 1143-1149

21 Brown M. R., Cohen H. J., Lyons J. M., Curtis T. W., Thunberg B., Cochran W. J. et al. (1986) Proximal muscle weakness and selenium deficiency associated with long term parenteral nutrition. Am. J. Clin. Nutr. 43: 549-554

22 Kelly D. A., Coe A. W., Shenkin A., Lake B. D. and WalkerSmith J. A. (1988) Symptomatic selenium deficiency in a child on home parenteral nutrition. J. Pediatr. Gastroenterol. Nutr. 7: 783-786
23 van Rij A. M., Thomson C. D., McKenzie J. M. and Robinson M. F. (1979) Selenium deficiency in total parenteral nutrition. Am. J. Clin. Nutr. 32: 2076-2085

24 Baptista R. J., Bistrian B. R., Blackburn G. L., Miller D. G., Champagne C. D. and Buchanan L. (1984) Suboptimal selenium status in home parenteral nutrition patients with small bowel resections. JPEN J. Parenter. Enteral. Nutr. 8: 542-545

25 Orndahl G., Rindby A. and Selin E. (1982) Myotonic dystrophy and selenium. Acta Med. Scand. 211: 493-499

26 Orndahl G., Rindby A. and Selin E. (1983) Selenium therapy of myotonic dystrophy. Acta Med. Scand. 213: 237-239

27 Gebre-Medhin M., Gustavson K. H., Gamstorp I. and Plantin L. O. (1985) Selenium supplementation in X-linked muscular dystrophy. Effects on erythrocyte and serum selenium and on erythrocyte glutathione peroxidase activity. Acta Paediatr. Scand. 74: 886-890

28 Orndahl G., Sellden U., Hallin S., Wetterqvist H., Rindby A. and Selin E. (1986) Myotonic dystrophy treated with selenium and vitamin E. Acta Med. Scand. 219: 407-414

29 Chariot P., Dubreuil-Lemaire M. L., Zhou J. Y., Lamia B., Dume L., Larcher B. et al. (1997) Muscle involvement in human immunodeficiency virus-infected patients is associated with marked selenium deficiency. Muscle Nerve 20: 386-389

30 Ward R. J. and Peters T. J. (1992) The antioxidant status of patients with either alcohol-induced liver damage or myopathy. Alcohol Alcohol. 27: 359-365

31 Moghadaszadeh B., Desguerre I., Topaloglu H., Muntoni F., Pavek S., Sewry C. et al. (1998) Identification of a new locus for a peculiar form of congenital muscular dystrophy with early rigidity of the spine, on chromosome 1p35-36. Am. J. Hum. Genet. 62: 1439-1445

32 Moghadaszadeh B., Petit N., Jaillard C., Brockington M., Roy S. Q., Merlini L. et al. (2001) Mutations in SEPN1 cause congenital muscular dystrophy with spinal rigidity and restrictive respiratory syndrome. Nat. Genet. 29: 17-18

33 Lescure A., Gautheret D., Carbon P. and Krol A. (1999) Novel selenoproteins identified in silico and in vivo by using a conserved RNA structural motif. J. Biol. Chem. 274: 38147-38154

34 Oksanen H. E. (1967) In: Selenium in biomedicine, chap. 14, pp. 224, Muth O. M. (ed.), Avi Publishing Co., Westport

35 Lamand M. (1970) [Biochemical lesions in calf myopathy by selenium deficiency]. C. R. Acad. Sci. Hebd. Seances Acad. Sci. D 270: $417-420$

36 Hill K. E., Motley A. K., Li X., May J. M. and Burk R. F. (2001) Combined selenium and vitamin E deficiency causes fatal myopathy in guinea pigs. J. Nutr. 131: 1798-1802

37 Hidiroglou M., Carson R. B. and Brossard G. A. (1968) Problems associated with selenium deficiency in beef calves. Can. J. Physiol. Pharmacol. 46: 853-858

38 Brigelius-Flohe R., Kelly F. J., Salonen J. T., Neuzil J., Zingg J. M. and Azzi A. (2002) The European perspective on vitamin E: current knowledge and future research. Am. J. Clin. Nutr. 76: 703-716

39 Whanger P. D., Pedersen N. D., Elliot D. H., Weswig P. H. and Muth O. H. (1972) Free plasma amino acids in selenium-deficient lambs and rats. J. Nutr. 102: 435-442

40 Black R. S., Tripp M. J., Whanger P. D. and Weswig P. H. (1978) Selenium proteins in ovine tissues: III. Distribution of selenium and glutathione peroxidases in tissue cytosols. Bioinorg. Chem. 8: $161-172$

41 Whanger P. D., Vendeland S. C., Beilstein M. A. (1993) In: Trace Elements in Man and Animals TEMA 8, pp. 119-126, Anke M., Meissner D., Mills C. L. (eds.), Verlag Media Touristik, Gersdorf

42 Tripp M. J., Whanger P. D. and Schmitz J. A. (1993) Calcium uptake and ATPase activity of sarcoplasmic reticulum vesicles isolated from control and selenium deficient lambs. J. Trace Elem. Electrolytes Health Dis. 7: 75-82

43 Beilstein M. A., Vendeland S. C., Barofsky E., Jensen O. N. and Whanger P. D. (1996) Selenoprotein W of rat muscle binds 
glutathione and an unknown small molecular weight moiety. J. Inorg. Biochem. 61: 117-124

44 Jeong D., Kim T. S., Chung Y. W., Lee B. J. and Kim I. Y. (2002) Selenoprotein $\mathrm{W}$ is a glutathione-dependent antioxidant in vivo. FEBS Lett. 517: 225-228

45 Lescure A., Gautheret D. and Krol A. (2002) Novel selenoproteins identified from genomic sequence data. Methods Enzymol. 347: 57-70

46 Muntoni F. and Guicheney P. (2002) 85th ENMC International Workshop on Congenital Muscular Dystrophy. 6th International CMD Workshop. 1st Workshop of the Myo-Cluster Project 'GENRE'. 27-28th October 2000, Naarden, The Netherlands. Neuromuscul. Disord. 12: 69-78

47 Ferreiro A., Monnier N., Romero N. B., Leroy J. P., Bonnemann C., Haenggeli C. A. et al. (2002) A recessive form of central core disease, transiently presenting as multi-minicore disease, is associated with a homozygous mutation in the ryanodine receptor type 1 gene. Ann. Neurol. 51: 750-759

48 Ferreiro A., Quijano-Roy S., Pichereau C., Moghadaszadeh B., Goemans N., Bonnemann C. et al. (2002) Mutations of the selenoprotein $\mathrm{N}$ gene, which is implicated in rigid spine muscular dystrophy, cause the classical phenotype of multiminicore disease: reassessing the nosology of early-onset myopathies. Am. J. Hum. Genet. 71: 739-749

49 Goldfarb L. G., Park K. Y., Cervenakova L., Gorokhova S., Lee H. S., Vasconcelos O. et al. (1998) Missense mutations in desmin associated with familial cardiac and skeletal myopathy. Nat. Genet. 19: 402-403

50 Goebel H. H. and Fardeau M. (2002) Desmin - Protein Surplus Myopathies, 96th European Neuromuscular Centre (ENMC)sponsored International Workshop held 14-16 September 2001, Naarden, The Netherlands. Neuromuscul. Disord. 12: 687-692

51 Nakano S., Engel A. G., Akiguchi I. and Kimura J. (1997) Myofibrillar myopathy. III. Abnormal expression of cyclin-dependent kinases and nuclear proteins. J. Neuropathol. Exp. Neurol. 56: $850-856$

52 Goebel H. H. and Warlo I. (2000) Gene-related protein surplus myopathies. Mol. Genet. Metab. 71: 267-275

53 Fardeau M., Godet-Guillain J., Tome F. M., Collin H., Gaudeau S., Boffety C. et al. (1978) [A new familial muscular disorder demonstrated by the intra-sarcoplasmic accumulation of a granulo-filamentous material which is dense on electron microscopy (author's transl)]. Rev. Neurol. (Paris) 134: 411-425

54 Rappaport L., Contard F., Samuel J. L., Delcayre C., Marotte F., Tome F. et al. (1988) Storage of phosphorylated desmin in a familial myopathy. FEBS Lett. 231: 421-425

55 Ferreiro A., Ceuterick-de Groote C., Marks J. J., Goemans N., Schreiber G., Hanefeld F. et al. (2004) Desmin-related myopathy with Mallory body-like inclusions is caused by mutations of the selenoprotein N gene. Ann. Neurol. 55: 676-686

56 Tajsharghi H., Darin N., Tulinius M. and Oldfors A. (2005) Early onset myopathy with a novel mutation in the Selenoprotein N gene (SEPN1). Neuromuscul. Disord. 15: 299-302

57 Venance S. L., Koopman W. J., Miskie B. A., Hegele R. A. and Hahn A. F. (2005) Rigid spine muscular dystrophy due to SEPN1 mutation presenting as cor pulmonale. Neurology 64: 395-396
58 D'Amico A., Haliloglu G., Richard P., Talim B., Maugenre S., Ferreiro A. et al. (2005) Two patients with ,Dropped head syndrome" due to mutations in LMNA or SEPN1 genes. Neuromuscul. Disord. 15: 521-524

59 Jimenez-Mallebrera C., Brown S. C., Sewry C. A. and Muntoni F. (2005) Congenital muscular dystrophy: molecular and cellular aspects. Cell. Mol. Life Sci. 62: 809-823

60 Petit N., Lescure A., Rederstorff M., Krol A., Moghadaszadeh B., Wewer U. M. et al. (2003) Selenoprotein N: an endoplasmic reticulum glycoprotein with an early developmental expression pattern. Hum. Mol. Genet. 12: 1045-1053

61 Sorrentino V. (2004) Molecular determinants of the structural and functional organization of the sarcoplasmic reticulum. Biochim. Biophys. Acta 1742: 113-118

62 Grewal P. K. and Hewitt J. E. (2003) Glycosylation defects: a new mechanism for muscular dystrophy? Hum. Mol. Genet. 12 Spec. No. 2: R259-264

63 Kanagawa M., Michele D. E., Satz J. S., Barresi R., Kusano H., Sasaki T. et al. (2005) Disruption of perlecan binding and matrix assembly by post-translational or genetic disruption of dystroglycan function. FEBS Lett. 579: 4792-4796

64 Michele D. E. and Campbell K. P. (2003) Dystrophin-glycoprotein complex: post-translational processing and dystroglycan function. J. Biol. Chem. 278: 15457-15460

65 Thisse C., Degrave A., Kryukov G. V., Gladyshev V. N., Obrecht-Pflumio S., Krol A. et al. (2003) Spatial and temporal expression patterns of selenoprotein genes during embryogenesis in zebrafish. Gene Expr. Patterns 3: 525-532

66 Michelson A. M., Russel E. S. and Harman P. J. (1955) Dystrophia muscularis: a hereditary primary myopathy in the house mouse. PNAS 41: 1079-1084

67 Hitaka T., Mizutani T., Watanabe K. and Totsuka T. (1990) The high content of natural suppressor serine tRNA in dystrophic mouse muscle. Biochem. J. 266: 201-206

68 Bosl M. R., Takaku K., Oshima M., Nishimura S. and Taketo M. M. (1997) Early embryonic lethality caused by targeted disruption of the mouse selenocysteine tRNA gene (Trsp). Proc. Natl. Acad. Sci. USA 94: 5531-5534

69 Kim L. K., Matsufuji T., Matsufuji S., Carlson B. A., Kim S. S., Hatfield D. L. et al. (2000) Methylation of the ribosyl moiety at position 34 of selenocysteine tRNA[Ser]Sec is governed by both primary and tertiary structure. RNA 6: 1306-1315

70 Warner G. J., Berry M. J., Moustafa M. E., Carlson B. A., Hatfield D. L. and Faust J. R. (2000) Inhibition of selenoprotein synthesis by selenocysteine tRNA[Ser]Sec lacking isopentenyladenosine. J. Biol. Chem. 275: 28110-28119

71 Moustafa M. E., Carlson B. A., El-Saadani M. A., Kryukov G. V., Sun Q. A., Harney J. W. et al. (2001) Selective inhibition of selenocysteine tRNA maturation and selenoprotein synthesis in transgenic mice expressing isopentenyladenosine-deficient selenocysteine tRNA. Mol. Cell. Biol. 21: 3840-3852

72 Hornberger T. A., McLoughlin T. J., Leszczynski J. K., Armstrong D. D., Jameson R. R., Bowen P. E. et al. (2003) Selenoprotein-deficient transgenic mice exhibit enhanced exercise-induced muscle growth. J. Nutr. 133: 3091-3097

73 Moosmann B. and Behl C. (2004) Selenoprotein synthesis and side-effects of statins. Lancet 363: 892-894 